\title{
Social, Biology and Economic Life of Children Links on Street-Begging in Bangladesh: A Cross-Cultural Multivariate Analysis
}

\author{
Md Kamruzzaman", Md Abdul Hakim², * \\ ${ }^{1}$ School of Victimology and Restorative Justice, Institute of Social Welfare and Research, University of Dhaka, Dhaka, Bangladesh \\ ${ }^{2}$ Department of Mathematics, Light House Laboratory School and College, Tangail, Bangladesh \\ Email address: \\ shohag.mbstu.cps@gmail.com (Md K.), hakimaffairs@gmail.com (Md A. H.) \\ ${ }^{*}$ Corresponding author
}

\section{To cite this article:}

Md Kamruzzaman, Md Abdul Hakim. Social, Biology and Economic Life of Children Links on Street-Begging in Bangladesh: A CrossCultural Multivariate Analysis. Mathematics Letters. Vol. 3, No. 1, 2017, pp. 107-114. doi: 10.11648/j.ml.20170301.12

Received: February 21, 2017; Accepted: March 18, 2017; Published: April 14, 2017

\begin{abstract}
The study was conducted at four upazilas in Dhaka city of Bangladesh taking $70.73 \%$ boys and $29.29 \%$ girls using convenience sampling method. About 41.46\% respondents were 2501-3000 BDT, 9.75\% were 1001-1500 BDT and 3001-3500 BDT earners having $82.92 \%$ respondents no link with other occupations. Some $53.66 \%$ fathers of the respondents were rickshaw pullers, $17.07 \%$ farmers and beggars as well as $46.34 \%$ mothers of respondents were housewives, $26.83 \%$ beggars and day labors in occupation. About $60.97 \%$ respondents came in begging from the slums and $63.41 \%$ respondents adopt begging due to their poverty and $34.15 \%$ were forced beggars.
\end{abstract}

Keywords: Poverty, Street-Begging, Socio-Economic Condition, Multivariate Analysis, Bangladesh

\section{Introduction}

Begging is the practice of imploring others to grant a favor, often a gift of money, with little or no expectation of reciprocation [1]. It means soliciting or receiving alms in public place, whether or not under any pretense such as singing, dancing, fortune telling, reciting holy verse or performing tricks; entering in any private premises for the purpose of soliciting or receiving alms; exposing or exhibition with the object obtaining or extorting alms any sore would, injury deformity or disease; having no visible means of subsistence and wandering about and remaining in any public place in such condition or manner as makes it likely that the person doing so exists by soliciting or receiving alms; and allowing oneself to be used as an exhibit for the purpose of soliciting or receiving alms under the provisions of Bangladesh Children Act, 1974, Section 2 (c) [2]. Begging is defined by the Buffalo Human Rights Law Review as "the activity" of asking for money as charity on the street $[3,4]$. Macdonald defined begging as asking for alms or charity given out of sympathy to the poor [5]. The simplest way of defining begging is to ask for money without any return of services [6] and it is a street level resource for the poor and powerless [7] and the solicits alms receivers to sustain livelihood are called beggars [8]. The definition of a beggar is very wide and all encompassing. A penniless person who begs alms or lives by begging or a person who has no money or resources is called beggar [9]. It is also said, a beggar is someone who lives by asking people for money or food [10]. Beggars are the members of the society who have been neglected entirely in many spheres in Nigeria, both socioeconomically and politically, they have no pride and dignity to protect in a society due to their begging business engagement. There are two main types of beggars: full-timers and part-timers. The former type of beggars engages in street-begging activity on regular-basis or daily-basis and openly done it, while the latter type of beggars engages in begging activity on irregular-basis or occasionally-basis and not done openly [11].

Beggars are found in public places such as transport routes, urban parks and near busy markets [12]. There are found mostly eight categories of beggars, such as Juvenile beggars; Physically and mentally handicapped; Diseased; Religious mendicants; Able bodied; Aged and infirm; Casual beggars who resort to begging only as a stop gap arrangement till they are able to secure some casual 
employment or part time work again; Professional/hereditary beggars: Certain communities consider begging as their profession and indulge in begging as a traditional or customary activity. This type of beggary is prevalent amongst the members of certain caste or tribal groups who lead a nomadic way of existence and earn their living by entertaining people through singing, dancing or performing acrobatic feats [13]. Besides money, they may also ask for food, drink or other small items [14]. The problem of beggary is not new and begging has been a traditional profession [15]. There are several cultural factors that support begging. In Europe begging is found in a number of minority cultures, especially popular within Roma and nomadic communities [16]. In Turkey familial networks of beggars have been documented across three generations, making it deeply ingrained within their survival schemas [17]. A UNICEF study reported that thirteen percent of trafficking victims in South Eastern Europe have been trafficked for the purpose of forced begging [18]. Forced begging is often imposed by family members, with parental power leveraged over a child to ensure that begging is carried out [19]. Although there are also begging mafia who force large number of children to beg [20]. These child beggars are involved with drug dealings and other delinquencies which lead them to be criminal [21].

The child beggars are a distinct category of the street children who are most deprived even with the basic needs and struggle to survive in different places across the globe [22]. These children are particularly the vulnerable group; where a child is prone to abuse, deprivation of basic needs, care and protection continuing a miserable lower class life [23].

The child beggars are the 'High Risk Groups of Children', children without adequate parental care [24, 25]. Literature suggests that refugee children, street children and children from low-income families are particularly vulnerable to exploitative labor practices, including exploitative employers, poor wages, lack of training and physically inappropriate demand, and higher risk of physical punishment and sexual abuse [26, 27]. Some children start begging or working on the street and returning home at night eventually leave home to live on the street [28]. The UNICEF defines street children as 'who is of the street and on the street' [29]. In Bangladesh numerous children live as street children in the big cities and towns particularly in Dhaka city. They live an inhuman life and a significant portion of them are involved in begging [30]. It has been estimated that more than 100 million street and working children around the world are struggling to survive under harsh and often exploitative conditions [31]. Children are the most vulnerable to be victimized [32]. Child beggars become victims when they experienced involuntary physical, sexual, emotional injuries, losses or death at the hands of another human being [33]. The may be victimized by adults and other children, by family members (parents, siblings, other relatives); by friends and acquaintances and by strangers [34]. The conditions in which begging takes place commonly expose children to further physical and verbal abuse, including sexual victimization and police brutality [35].

The child beggars in Bangladesh have been recognized by many literatures as such a category of the street children who lack the proper requirements of life and they are tagged as 'severely deprived' children [36]. These severe deprivation can be found with their not having the adequate services in the provision of shelter, sanitation, water, information, nutrition, education, and health etc [37]. Despite constitutional recognition of the right to shelter for all citizens, 41 percent of all children are deprived of adequate shelter [38]. It can be well assumed that, a major portion of these children are the child beggars. At policy and program levels, there is little provision for providing shelter facilities to poor, homeless households, or children living on the streets and this picture are reflected also in the other provision of life requirements for the street children and more specifically the child beggars [39]. In Bangladesh, there is a lack of comprehensive data on street dwellers or people with similar Condition such as their number, living conditions and livelihood activities. Different small Scale surveys give some idea about their numbers. According to a government estimate, there are 250,000 street children in Dhaka city [40]. Also, there were 100,000 beggars in the city and about 4,000 to 6,000 were disabled among them [41].

While a small but growing body of research describes the lives of people who live in urban informal settlements or slums, very little research describes the population with no housing at all [42]. Many of them have been coming to Dhaka by the process of migration. And Dhaka city, being the capital and land of 'opportunities', has to take the major brunt of this influx of migrant population. In line with this, the homeless population in Dhaka, of which a significant number is the child beggars; is known to face extortion, erratic unemployment, exposure to violence, sexual harassment, and to engage in high-risk behaviors [43, 44].

Begging is a social problem, considering as a violation of public order and it is prohibited by the Dhaka Metropolitan Police Ordinance III of 1976. There have a vagrant act which is implemented outside the metropolitan area. According to ordinance number 81 , begging is one kind of crime and there have one month punishment who beg or try to beg or who try for coming sympathy of others through showing any physical injury, diseases, skin diseases or showing misbalance position of the organs of his or her bodies for the intention of having some beg [45]. It is also prohibited in many cities all over the world like Dhaka in Bangladesh [46, 47].

According to Section 70 of Bangladesh Children Act 2013, forced child begging is highly prohibited by law and if anyone engaged a child in begging by force will be punished with five years imprisonment or one lac taka fine or both [48, 89].

The Universal Declaration of Human Rights of 1948 in its Article 25 stated that, "Everyone has the right to a standard of living adequate for the health and well-being of himself and his family, including food, clothing, housing, medical care and necessary social services and the right to security in the event of unemployment, sickness, disability, widowhood, old age or other lack of livelihood in circumstances beyond 
his control" [49]. Section 85 of Children Act, 2013 says, the homeless, destitute children found in begging will get proper food, clothe, education and shelter should get shelter from the state [50]. The government is bound to provide those by rehabilitation centers, Child family and Sotomoni Nibash etc. [51]. But the child beggars hardly getting their rights to grow up as human being [52].

States parties shall recognize for every child the right to benefit from social security, including social insurance and shall take the necessary measures to achieve the full realization of this right in accordance with their national law [53]. All human beings are born free and equal in dignity and rights [54]. In 1948, the UN General Assembly passed the Universal Declaration of Human Rights, which referred childhood as entitled to "special care and assistance" [55-56]. The child beggars are the different diseases sufferers on the basis of seasonal variation and some are chronic health disorders sufferers according to their dwelling topographic variation [57-59]. About $73 \%$ of child beggars in Dhaka city suffer from chronic malnutrition while mortality and morbidity status among street dwellers has reached an alarming level for lack of basic health and nutritional care services [60-62, 86, 87, 91].

It is argued that there is strong relationship between street begging, disability and poverty in many societies. It is equally assumed that those that engaged in begging do so because they are being trapped in a "Vicious Cycle of Poverty" and see the former as a last resort for their survival $[88,92]$. Furthermore, the poor people are at the greater risk to become disabled through lack of adequate housing, food, clean water, basic sanitation and safe working environments. While in return, disabled people are at higher risk to become poor through restricted access to education, health care, job training and employment opportunities $[63,90]$. Therefore the current research was designed to provide empirical outputs of the socioeconomic status, nature and causes of violence against them, health and nutritional situation of the child beggars in Bangladesh.

\section{Framework and Data Sources}

\subsection{Study Type}

The study was a pilot study.

\subsection{Population Selection}

There were taken a total 108 child at different slums on Dhaka city in Bangladesh.

\subsection{Study Duration}

The study was conducted from July 2013 to May 2014 .

\subsection{Sampling Method}

The non-probability (Convenience sampling) method was used to frame the beggars from the study places.

\subsection{Data Collecting Techniques}

A planned questionnaire was developed containing both the closed and open ended query to collect data through faceto-face interview with the respondents. The questionnaire was pretested in areas far away from the sample areas and revised according to the feedback gained in the field level. The questionnaire was formed to obtain the relevant information considering personal, household, social and economic details.

\subsection{Data Verification}

The questionnaire was checked per day taking the interview and gain these were carefully rechecked after collecting all the data and coded prior the entrancing into computer technology.

The data was edited in case of sighting discrepancy (doubt entry, wrong entry etc.)

\subsection{Statistical Analysis}

The data were processed to undergo statistical analysis using SPSS 16 windows program. Microsoft Word, Microsoft Excel were used to represent the tabular and chart icon.

\section{Results}

There were found that maximum number $(37.59 \%)$ of respondents were in 7-10 years of ages, $28.36 \%$ respondents within 11-14 years and very few (12.05\%) within 3-6 years. Some $33.33 \%$ fathers of respondents were Rickshaw pullers and $41.84 \%$ mothers were housewives according to the study (Table 1).

Table 1. Socio-Demographic characteristics of the respondents.

\begin{tabular}{lll}
\hline Parameters & Frequency & Percentage \\
\hline Sex & 79 & 56 \\
Boys & 62 & 44 \\
Girls & & \\
Age (years) & 17 & 12.05 \\
3-6 & 53 & 37.59 \\
$7-10$ & 40 & 28.36 \\
$11-14$ & 31 & 21.98 \\
$15-18$ & & \\
Father's occupation & 47 & 33.33 \\
Rickshaw pullers & 29 & 20.56 \\
Farmers & 33 & 23.40 \\
Beggars & 32 & 22.69 \\
Small Traders & & \\
Mother's occupation & 59 & 41.84 \\
Housewives & 36 & 25.53 \\
Day Labors & 46 & 32.62 \\
Beggars & & \\
Educational Qualification & & 24.11 \\
Primary & 107 & 75.89 \\
Illiterate & & \\
\hline
\end{tabular}

There were observed that $53.90 \%$ respondents in begging profession by dint of their poverty and $38.29 \%$ were forced beggars came from slums (46.1\%). About 26.24\% 
respondents earned 2501-3000 BDT (highest) and 14.89\% earned 1001-1500 BDT (lowest). 26.24\% beggars had no relation with other occupations while $29.78 \%$ were added with drug dealings and $43.97 \%$ with labors keeping no relation with their families $(71.63 \%)$ (Table 2$)$.

Table 2. Socio-economic characteristics of the respondents.

\begin{tabular}{lll}
\hline Parameters & Frequency & Percentage \\
\hline Causes of being beggars & & \\
Poverty & 76 & 53.90 \\
Force giving & 54 & 38.29 \\
Others & 11 & 7.80 \\
Comes from & & \\
Villages & 51 & 36.17 \\
Towns & 25 & 17.73 \\
Slums & 65 & 46.1 \\
Monthly Income (BDT) & & \\
$<1500$ & 26 & 18.43 \\
1501-2000 & 21 & 14.89 \\
2001-2500 & 33 & 23.40 \\
2501-3000 & 37 & 26.24 \\
$>3000$ & 24 & 17.02 \\
Relationship with other occupations & \\
Labors & 62 & 43.97 \\
Drug dealings & 42 & 29.78 \\
No relations & 37 & 26.24 \\
Relationship with their families & & \\
Yes & 40 & 28.37 \\
No & 101 & 71.63 \\
Reasons of leaving family & & \\
Parents death & 18 & 17.82 \\
Parents disowned & 11 & 10.89 \\
To Earn & 29 & 28.71 \\
Did not like family & 10 & 09.90 \\
Run away after stealing & 12 & 20.79 \\
Violence at home & 21 & \\
\hline & & \\
& & \\
\hline
\end{tabular}

According to the table 3 statement, $27.66 \%$ and $29.78 \%$ respondents adopted the begging due to their parents and friends respectively and $12.76 \%$ were forced by terrorists. $53.19 \%$ respondents said that they took cigarette, $19.85 \%$ alcohol and $21.98 \%$ ganja seeking anonymities.

Table 3. Nature of Violence against Child beggars.

\begin{tabular}{lll}
\hline Parameters & Frequency & Percentage \\
\hline Doing begging (forced by whom) & & \\
Friends & 42 & 29.78 \\
Parents & 39 & 27.66 \\
Neighbors & 22 & 15.60 \\
Terrorists & 18 & 12.76 \\
Kidnappers & 20 & 14.18 \\
Types of drugs taking & & \\
Cigarette & 75 & 53.19 \\
Ganja & 31 & 21.98 \\
Alcohol & 28 & 19.85 \\
Faced Tortured & & \\
Yes & 141 & 100 \\
No & 0 & 0 \\
By whom Faced Tortured & & \\
Public & 61 & 43.26 \\
Gang leader & 45 & 31.91 \\
Parents & 6 & 04.25 \\
Friends & 29 & 20.57 \\
Injury for Doing this Profession & & 30.50 \\
Yes & 43 & \\
\hline
\end{tabular}

\begin{tabular}{lll}
\hline Parameters & Frequency & Percentage \\
\hline No & 98 & 69.50 \\
Types of Injury & & \\
Hand cutting & 13 & 30.23 \\
Leg cutting & 19 & 44.18 \\
Damaged the power of eyes & 11 & 25.58 \\
Behavior of the General People & & \\
Good & 16 & 11.34 \\
Rude & 125 & 88.65 \\
What happens if they don't beg? & & \\
Starve & 85 & 60.28 \\
Parents beat & 22 & 15.60 \\
Can't help family & 26 & 18.44 \\
Forced to leave study & 5 & 03.55 \\
Nothing & 3 & 02.13 \\
\hline
\end{tabular}

Table 4. Aspirations of the respondents.

\begin{tabular}{lll}
\hline Parameters & Frequency & Percentage \\
\hline Do you like beg? & & \\
Yes & 49 & 34.75 \\
No & 92 & 65.25 \\
Willingness to go to school & & \\
Yes & 53 & 37.59 \\
No & 88 & 62.41 \\
Willingness to take skill training & & \\
Yes & 38 & 26.95 \\
No & 82 & 58.15 \\
Cannot say & 21 & 14.89 \\
\hline
\end{tabular}

Table 5. Health and nutritional status of the respondents.

\begin{tabular}{lll}
\hline Parameters & Frequency & Percentage \\
\hline Daily meal taken frequency & & \\
4 & 0 & 00.00 \\
3 & 82 & 58.15 \\
2 & 59 & 41.84 \\
1 & 0 & 00.00 \\
Hand washing before eating & & \\
Yes & 119 & 84.39 \\
No & 22 & 15.60 \\
Daily bath taken & & \\
Yes & 85 & 60.28 \\
No & 56 & 39.71 \\
Suffering from diseases in last 3 months & \\
Yes & 92 & 65.24 \\
No & 49 & 34.75 \\
\hline
\end{tabular}

\section{Discussion}

Begging is one of the most alarming and horrific forms of violence [63]. It is a most violent phenomenon for whole world [64]. In Bangladesh, children involved in begging are also facing this violent alarmingly [65] and the number of child beggar is increasing day by day [66]. The children are in deprivation to their rights to rights to survival, education, health, nutrition and safe childhood [67].

The present study undertook a survey to assess the number of child beggars in the capital city Dhaka and central district Tangail of Bangladesh as most populated area, where also conducted in depth interviews of 141 child beggars. The study covered the socio-demographic, nutritional status and health hygiene practices of the child beggar. Found that most of the children were initiated into begging in their childhood itself, mostly by their own parents or occasionally by 
relatives. Gender distribution of child beggars shows that begging is more prevalent among boys than girls. Most of the respondents were boys $(68.6 \%)$ and $44.3 \%$ respondents were within $14-18$ where $21.4 \%$ belongs to the age group $4-8$ years according to the study. There were found that maximum $(74.2 \%)$ respondents were the family members of more than 3 siblings. Another study shows that, majority of the child beggars $(66 \%)$ are boys and $77 \%$ are in age ranging 10 to 14 years which slightly differs from the current study [68].

There were observed that $38.6 \%$ respondents were 2501 3500 and $14.3 \%$ were more than 3500 BDT earners to manage 3 times meal per day by $61.4 \%$ while 2 times snacks per day by $5.7 \%$ respondents. According to other study, child beggar earns a total of Tk. 172 daily (including income from other sources) and most of them could manage 2 times meal per day [69]. According to present study, some $81.4 \%$ respondents washed their hand before eating and $72.8 \%$ brushed their teeth once a day while about 38. $6 \%$ respondents took bath now and then and the rest $61.4 \%$ took daily. It is also found $62.8 \%$ underweight plus $5.7 \%$ overweight while a tiny portion $31.4 \%$ was in ideal weight sustainers and most of the illiterate child beggars were underweight which is similar to another study [70-72].

In Bangladesh, as in many developing countries, there is a widespread belief amongst the public, policymakers and social workers that children 'abandon' their families and migrate to the street as beggar because of economic poverty $[73,74]$.

According to the Article 17, 18 (1) and 19 of the constitution of Bangladesh, the state should take proper measures of free and compulsory education, raising the level of nutrition and improvement of health for the children along with equal economic development throughout the country and to fulfilling this condition; the government of Bangladesh under the Ministry of Social Welfare builds up five vagrancy centers. But most of the beggars do not want to spend their time into the vagrancy centers because of various problems along with insufficient food and nutrition facility, treatment opportunity, rehabilitation insecurity, recreational lacking and so on [75-77].

Considering the overall study, it felt that the life of child should be begging and exploitation free on the basis of the existing laws to eradicate the child abuse to arrange safe childhood [78-80]. Group counseling can be an effective measure to solve this ongoing problems in Bangladesh as well in the world also while prevailing multidimensional perilous condition [81-85].

\section{Conclusions}

Begging, especially the child begging is the curse for the society affecting the total image of the country. Beggars are the low income earners, not sufficient to survive in the society maintaining the basic needs and the luxurious hopes is on the brown study. Good governance along with NGOs should come up with their helping hands to combat the vagrancy problems in Bangladesh.

\section{Recommendations}

Beggary is primarily an outcome of abject poverty and not choice in most cases, as the study demonstrates. Mostly parents and relatives or acquaintances of the children are pushing them into begging. Children who come from families where situations of extreme poverty and lack of access to employment prevails such children beg for their families' survival. The study has clearly brought out the vulnerability of the children engaged in begging. To effectively deal with the problem of child beggars following suggestions are made:

a. The conditions in which child beggars work are certainly hazardous as per the ILO definition which states "Hazardous work by children is defined as any activity or occupation that, by its nature or type, has or leads to adverse effects on the child's safety, health and moral development". (ILO; 2013: p. 16). Hence child beggars should be covered under various child labour schemes of the Ministry of Labour.

b. Training of law enforcement officers should cover issues like homelessness, begging and need for empathetic engagement as well as understanding of the need for early intervention, early diversion, referral and cautionary strategies as preventive measures.

c. As part of Advocacy members of the society should be sensitized regarding the issue of urban poverty and destitution and how they can contribute to poverty alleviation. Also why one time charity is harmful.

d. There is an overlap between child beggars, child labour and street children becausechild beggars engage themselves in rag picking and vending also hence they shouldform part of all the programmes relating to child labour and street children.

e. Child beggars are being abused by adults be it their own parents, relatives or acquaintances. Such adults should be dealt with as per the provisions of Section 24 of the Juvenile Justice Act 2000 which provides punishment for employing a juvenile ora child for begging.

f. As most of the children are not in school, though as per this study good number ofchild beggars have expressed their willingness to study and acquire skill training, there is an urgent need to provide appropriate education, both formal schooling and skill training, suiting to their requirements.

g. Access to basic necessities, such as, safe shelters, food, clothing, safe drinking water, sanitation and education should be provided to all as a matter of right and should ensure that the benefits reach the end beneficiaries.

h. Awareness about government and NGO schemes/programmes should reach the children so that they could benefit from those.

i. Most child beggars belong to the poorest of the poor who have migrated with their parents to urban centres as a survival strategy. Children should be facilitated in getting identity proof, which the government accepts as an entitlement document. This will facilitate opening of 
their bank accounts, get admission in schools, etc.

j. It is essential to increase the number of family shelters, drop-in-shelters ren- baseras where children along with their parents can stay. Night classes and other services can also be centered around such places.

k. The government should ensure that appropriate services of doctors, counsellors, and social workers are provided to these children.

1. Localized target oriented community based programmes should be planned and administered at the points where the child beggars congregate mainly with their families. Parents need to be counselled to spare their children for education and skill development since majority of children stay with their families.

m. Multi pronged intervention strategies are needed in rural areas to reduce migration from rural to urban areas. Employment possibilities for adults should be increased dramatically in those rural areas from where large-scale out-migration is taking place.

n. To bring down the incidence of child beggars interventions are needed to strengthen their families by providing jobs, better housing and increased number of schools for poor children in both rural and urban areas. Compensation should be given to the parents/children in the form of stipend on the basis of school attendance.

o. Schools should have sympathetic teachers, child friendly environment and should ban corporal punishment.

\section{References}

[1] Dromi SM. Penny for your Thoughts: Beggars and the Exercise of Morality in Daily Life". Soc Forum 27 (4): 847871.

[2] Sarkar AH. Juvenile Delinquence 2001; p. 258.

[3] Kamruzzaman M and Hakim MA. Socio-economic Status of Child Beggars in Dhaka City. Journal of Social Sciences and Humanities 2015; 1 (5): 516-520.

[4] Delap E. Begging For Change: Research findings and recommendations on forced child begging in Albania/Greece, India and Senegal. Anti-Slavery International 2009.

[5] Macdonald AM. Chambers Twentieth Century Dictionary, Chambers, Edinburgh, 1972.

[6] Fitzpatrick S and Kennedy C. Getting By: Begging, Rough Sleeping and the Big Issue in Glasgow and Edinburg, Policy Press, Bristol, 2000.

[7] Jordan B. Begging: the global context and international comparisons", in Dean, H. Begging questions: stress level economic activity and social policy failure. The policy press. Bristol, UK, 1999.

[8] Beggar, Retrieved on 2th February 2016, from http://www.thefreedictionary. com/beggar.

[9] Beggar, Retrieved on 2th February 2016, http://dictionary.reference.com/browse/beggar.
[10] Beggar, Retrieved on 2th February 2016, http://dictionary.reverso.net/english-cobuild/beggars.

[11] Esan OI. Panhandlers as Rhetors: Discourse Practices of Peripatetic Beggars in Southwestern Nigeria. California Linguistic Notes 2009 Vol. XXXIV. No. 2.

[12] Lynch P. Understanding and responding to begging (Australia). Melbourne: University Law Review 2005.

[13] Gupta BCD. Beggar: a menace to public health. In J. M. Kumarappa (Ed.), Our beggar problem: how to tackle it. Bombay: Padma Publications Ltd. 1945; p. 41-52.

[14] Begging, Retrieved on 2th February 2016, https://en.wikipedia.org/wiki/ Begging.

[15] Bulsara JF. A. scheme for the gradual tackling of the beggar problem with special reference to the city of Bombay. In J. M. Kumarappa (Ed.), Our beggar problem: how to tackle it. Bombay: Padma Publications Ltd. 1945; p. 119-157.

[16] Cherneva I. Human Trafficking For Begging. Buffalo Human Rights Law Review 17 (2011): 25. LexisNexis Academic: Law Reviews.

[17] Craig, Gary. Child Slavery Now. Portland: The Policy Press 2010.

[18] Ansari, MR. Protecting Human Rights, New Delhi: Max Ford Books. Balaganessin, M (2012, October 7), Child beggars: Tiruchi yet to 'wake up' to the sordid saga, The Hindu. (2006).

[19] Sinha, Kounteya (2008, January 24) 'Every Three Seconds One Child Dies in India: UNICEF', New Delhi The Times of India.

[20] Rubina Iqbal, (2013). "Begging a growing menace in India", International Journalof Advanced Research in Management and Social Sciences, Vol. 2 No. 8, August 2013, pp. $37-62$.

[21] Sharma, Rajendar Kumar (2004). Urban Beggary, "Urban Sociology ", Atlantic Publishers \& Distributers, New Delhi, 2004, p. 246.

[22] Kamruzzaman $M$ and Hakim MA. Child Criminalization at slum areas in Dhaka City. Am J Psychol Cog Sci 2015; 1 (4): $107-111$.

[23] Kennedy, Catherine and Fitzpatrick, Suzanne 'Begging, Rough Sleeping and Social Exclusion: Implications for Social Policy' (October 2001) Vol. 38 No. 11 Urban Studies 2001- 2016.

[24] Report on 'Community-Based Support (CUBS) Project for Orphans and Vulnerable Children in Nigeria', 2010.

[25] Wells, Matthew. "Off the Backs of the Children: Forced Begging and Other Abuses Against Talibes in Senegal." New York, New York: Human Rights Watch, 2010.

[26] Goel, A., (2010). Indian anti-beggary laws and their constitutionality through the prism of fundamental rights with special reference to Ram Lakhan V. State. Asia Pacific Journal on Human Rights and the Law, 11 (1), 23-38.

[27] United Nations Children's Fund Innocenti Research Centre, Child Trafficking in the Nordic Countries, Rethinking strategies and national responses, A Technical Report, 2012, pp. 34-41.

[28] UNICEF report on 'Situation analysis of children in South Africa', 2009 
[29] Child Beggars, (2016) Dalit Freedom Network Australia, Retrieved on 3 February 2016 fromhttp://www.dalitfreedom.org.au/trafficking/childbeggars.html? fontstyle $=$ f-larger.

[30] Abdul-Hamid, 2011.

[31] Aktar, 2004, as cited in Nawaz, 2011.

[32] Conticini and Hulme, 2005, as cited by Nawaz, 2011.

[33] Kamruzzaman, M., (2015). Child Victimization at Working Places in Bangladesh, Journal of Social Sciences and Humanities, 1 (5): 516-520.

[34] Benítez, 2001.

[35] Wells, Matthew. "Off the Backs of the Children: Forced Begging and Other Abuses Against Talibes in Senegal." New York, New York: Human Rights Watch, 2010.

[36] Finkelhor, D. The victimization of children: A. developmental perspective. American Journal of Orthopsychiatry 1995; 65, 2: 177-93.

[37] Driscoll, D. M., Kelly, J. R., \& Henderson, W. L. 1998. Can perceivers identify likelihood to sexually harass? Sex Roles, 38 (7-8): 557-588.

[38] Hakim, M. A., Kamruzzaman, M. Nutritional Status of Central Bangladesh Street Children, Am J Food Sci Nutr Res 2015; 2 (5): 133-137.

[39] Rao, T. S., \& Bogaert, M. V. D. (1970). The Beggar Problem in Ranchi. The Indian Journal of Social Work, 31 (3), 285302 .

[40] National Report of Bangladesh on 'Global Study on Child Poverty and Disparities'; UNICEF, 2009.

[41] Leading studies were conducted in Dhaka, Mexico City, Quito, Bombay, Madras and elsewhere. Black, 1996.

[42] The Daily Star (www.thedailystar.net), 12 December 2007; as referred to in Ahmed et. al, 2011.

[43] The New Nation (www.thedailynewnation.com), 1 February 2010; as mentioned in Ahmed et. al., 2011.

[44] Mander, Harsh (2009, January 25), The war against begging, The Hindu.

[45] Dhaka Metropolitan Police Ordinance no 3 of 1976 (20 January 1976) from http://bdlaws.minlaw.gov.bd.

[46] Datta, Sandeep, Child begging: The bane of modern India, Retrieved on 10 August 2013, from $\mathrm{http}: / / \mathrm{www} \cdot \mathrm{merinews.com} /$ article/child-begging-the-bane-ofmodernindia/125190.

[47] Ghosh, Ravi S, Begging Prohibition Act, (2013) Retrieved on 8 August 2013, from http://www.countercurrents.org/ghosh080410.htm.

[48] Children Act, 2013, www.bdlaws.minlaw.gov.bd.

[49] Enakshi Ganguly Thukral, Bharti Ali and Farhana Yasmin (2015). Politics, Pasia or Priorities: Where do Children fit into the 2015-16 Union Budget? HAQ; Centre for Child Rights and CRY, New Delhi.

[50] The State v Roushan Mondal and Hashem, 59 DLR72.
[51] Beggars in dhaka city: profession or compulsion Asian Journal of Business and Economics Volume 4, No. 4.3 Quarter III 2014, ISSN: 2231-3699.

[52] Mukherjee, D. (2008). Laws for beggars, justice for whom: A critical review of the Bombay prevention of begging Act 1959. International Journal of Human Rights, 12 (2), 279-288.

[53] Street Children in Morocco: Analysis of the Situation', in The link - The Official Newsletter of the International Society for Prevention of Child Abuse and Neglect (ISPCAN), USA; Vol. 15; No. 3, 2006.

[54] http://www.un.org/Overview/rights.html\#a1.

[55] Convention on the Rights of the Child, 1989, http://www.ohchr.org/en/professional interest/pages/crc.aspx.

[56] Rai, Rahul (2000), Human Rights: U N Initiatives, Delhi: Authors Press, Delhi.

[57] Kolosov, 'The Rights of the Child', Janusz Symonides (ed), Human Rights: Concepts and Standards, Rawat, Jaipur, 2002.

[58] Tripathi, S. C. and Arora, Vibha (2010), Law Relating to Women and Children, Allahabad: Central Law Publications.

[59] Rahman, A. and Sapkota, M. (2014), Knowledge on vitamin A rich foods among mothers of preschool children in Nepal: impacts on public health and policy concerns, Sci J Public Health, 2 (4), pp. 316-322.

[60] Kuddus, A. and Rahman, A., Talukder, M. R. and Hoque, A. (2014). A modified SIR model to study on physical behavior among smallpox infective population in Bangladesh, Am $J$ Math Stat 4 (5), pp. 231-239.

[61] Rahman, A. and Kuddus, A. (2014). A new model to study on physical behaviour among susceptible infective removal population, Far East $J$ Theor Stat 46 (2), pp. 115-135.

[62] [60] Rahman, A. and Chowdhury, S. (2007). Determinants of chronic malnutrition among preschool children in Bangladesh, J Biosoc Sci 39 (2), pp. 161-173.

[63] Nora, G. et al. (2014). Disabled Beggars in Addis Ababa: Current Situation and Prospects for Change. International Labour Organization, ILO. p. 9-10.

[64] Dabir, Neela and Athale, Naina (2011), From Street to Hope, New Delhi: Sage.

[65] Lynch, P. (2005). Understanding and responding to begging (Australia). Melbourne: University Law Review.

[66] World Bank, "Dhaka: improving living conditions for the urban poor". Report no. 35824-BD. Urban Development Unit South Asia Region. World Bank, Washington, DC 2006.

[67] Situational Analysis of the Street Children involved in Begging in Dhaka City, Human Development Research Center, November, 2012, www.hdrc-bd.com.

[68] Rabbany, Golam, "Beggars problem in Bangladesh". Narijibon Blog, 2007.

[69] Rahman, A., Chowdhury, S., Karim, A. and Ahmed, S. (2008). Factors associated with nutritional status of children in Bangladesh: A multivariate analysis. Demography India, 37 (1), pp. 95-109. 
[70] Sanderson, David, "Building livelihoods to reduce risk among the most marginalized in urban areas: strategic approaches from Dhaka", Centre for Development and Emergency Practice (CENDEP). Oxford Brooks University, Gipsy lane, Oxford, UK, 2012.

[71] Hakim MA and Kamruzzamanm M. Nutritional Status of Preschoolers in Four Selected Fisher Communities. Am J Life Sci 2015; 3 (4): 332-336.

[72] Hakim MA. Nutritional Status and Hygiene Practices of Primary School Goers in Gateway to the North Bengal. Int $J$ Public Health Res 2015; 3 (5): 271-275.

[73] Hakim MA and Rahman A. Health and Nutritional Condition of Street Children of Dhaka City: An Empirical Study in Bangladesh. Sci J Public Health 2015; 4 (1-1): 6-9.

[74] Hossain, Shahadat, "Social characteristics of a megacity: a case of Dhaka city, Bangladesh". TASA conference, University of Western Australia \& Murdoch University, 2006.

[75] ICDDR, B (2010) Street dwellers performance for health care services in Dhaka, Bangladesh. Dhaka: ICDDR, B.

[76] Kabir F. Shamim I, (1998) Child trafficking: the underlying dynamics. Dhaka: Center for Women and Children Studies. p. 88.

[77] Rashid, Mamun, "Banking for beggars", The Daily Star (www.thedailystar.net), 2005.

[78] Gore, M. S. (1959), The Beggar Problem in Metropolitan Delhi, Delhi: Delhi School of Social Work.

[79] Pachauri, S. K. (1999), Children and Human Rights, New Delhi: A P H Publishing Corporation.

[80] Save the Children (2011). Regional Report on Child Begging: Prevalence, Prevention and Suppression of Child Begging.

[81] Gillin, J. L. (1929, November), Vagrancy and begging, American Journal of Sociology, 35 (3): 37.

[82] Onagun AI. Relationship Between Street-Begging and Poverty in Ilorin Emirate, Kwara State, Nigeria. Int J Health Econ Pol 2016; 1 (1): 6-11.
[83] Hakim MA. Malnutrition Prevalence and Nutrition Counseling in Developing Countries: A Case Study. Int J Nur Health Sci 2016; 3 (3): 19-22.

[84] Hakim MA. Nutrition Counseling in Homelessness: A NC4HD Nexus. Int J Health Econ Pol 2017; 2 (1): 12-15.

[85] Hakim MA and Kamruzzaman M. The Dance of Poverty and Education for Childhood Nutritional Victimization in Bangladesh. J Biol Env Engg 2016; 1 (1): 6-9.

[86] Kamruzzaman M, Islam MA, Islam MS, Hossain MS and Hakim MA. Plight of Youth Perception on Cyber Crime in South Asia. Am J Info Sci Computer Engg 2016; 2 (4): 22-28.

[87] Kamruzzaman M. and Hakim MA. Factors Associated with the Suicidal Tsunami as a Mental Illness: Findings from an Epidemiological Study. Am J Env Sustain Devt 2016; 1 (1): 15.

[88] Rahman A and Hakim MA. An Epidemiological Study on Hygiene Practice and Malnutrition Prevalence of Beggars Children in Bangladesh. Int J Nutr Diet 2016; 4 (1): 29-46.

[89] Rahman A, Hakim MA, Hanif MA, Islam MR and Kamruzzaman M. Dietary Practices, Health Status and Hygiene Observance of Slum Kids: A Pilot Study in an Asian Developing Country. JP J Biostat 2016; 13 (2): 195-208.

[90] Kamruzzaman M and Hakim MA. Basic Rights on the Wane, Human Rights on Brown Study: A Case Study on Thrown Away Children in Bangladesh. Int J Env Plan Manage 2016; 2 (4): 29-35.

[91] Kamruzzaman M and Hakim MA. Prevalence of Acid Crime Victimization in South Asia: A. Review. J Biol Env Engg 2016; 1 (2): 17-22.

[92] Hakim MA, Talukder MJ and Islam MS. Nutritional Status and Hygiene Behavior of Government Primary School Kids in Central Bangladesh. Sci J Public Health 2015; 3 (5): 638-642.

[93] Hakim MA. Biophysical modeling of dietary energy in biochemical modeling. Am J Appl Industrial Chem, in press.

[94] Rahman A and Hakim MA. Modeling health status using the logarithmic biophysical modulator. $J$ Public Health Epidemiol, in press. 